\title{
ANTIGONE FOR THE AGE OF TERROR: TRANSTEXTUALITY IN
} KAMILA SHAMSIE'S HOMEFIRE

\author{
Saba Johar Khan ${ }^{1}$, Imdad Ullah Khan ${ }^{2 *}$, Saira Asghar Khan ${ }^{3}$, Laraib Rahat ${ }^{4}$, Shahreena ${ }^{5}$ \\ ${ }^{1,3}$ Fatima Jinnah Women University, Pakistan; ${ }^{2 *}$ University of Swat, Pakistan; ${ }^{4}$ Women University Swabi, Pakistan; \\ ${ }^{5}$ University of Lahore, Pakistan. \\ Email: ${ }^{1}$ sabakhanswb@gmail.com, ${ }^{2 *}$ imdad.Khan@ uswat.edu.pk, ${ }^{3}$ sairakhan@fjwu.edu.pk, ${ }^{4}$ khanmaryy236@gmail.com, \\ ${ }^{5}$ shirin.hakimi44@gmail.com
}

Article History: Received on $17^{\text {th }}$ June 2021, Revised on $28^{\text {th }}$ June 2021, Published on $29^{\text {th }}$ June 2021

\begin{abstract}
Purpose: The current qualitative study attempts to explore intertextuality in Kamila Shamsie's novel Homefire, published in 2017. This paper attempts to analyze the role it plays in the creation and understanding of meaning by employing Gerard Genette's theory of Intertextuality (Genette's Transtextuality).

Methodology: For this purpose, the study is conducted from the postmodern theoretical perspective of Intertextuality. Homefire is a modern retelling of Sophocles' Antigone. The novel captures the enigma of British Muslims struggling to defend their loyalty to the crown while maintaining their unique cultural and religious identities, in the wake of rising islamophobia in Britain.
\end{abstract}

Main Findings: The study finds that the interwoven intertextuality not only provides a basic framework for the plot and characters, but also juxtaposes the ancient world with the contemporary world along with the invariable conflicts, complexities, and similarities.

Implications: This study shows that the face of human conflict might get changed but the integral emotions and conflicts remain the same. This implies that using intertextual references enhances the text with poignant meanings through ages.

Novelty/Originality: Homefire as a recent text talking about islamophobia in Britain being a retelling of a classical Sophocles play is something that.

Keywords: Kamila Shamsie, Intertextuality, Gerard Genette, Transtextuality, Home Fire.

\section{INTRODUCTION}

Donne once wrote, "No man is an island" and certainly for many twenty-first-century authors, no text is an island. A text can't exist in isolation, separate from the ocean of other texts. Contemporary writing is all about connections between texts. That is not to say that previous texts had no connections. Kristeva (1980) posits that no text is solely the brainchild of an author. Authors owe their works to previous discourses (Allen, 2006). Every text that is created is influenced by some previous text(s) since these texts play a key role in influencing the author's aesthetics and choices (Allen, 2006; Huckin, 2004). Authors have had always drawn upon the already existing cultural norms, ideology, concept, or rhetoric from their surroundings as well as drawn upon other writings to assemble their creation (Barton, 2004; Bhabha, 2004; Gee, 1996). Intertextuality in a text is inevitable therefore a reader's awareness about intertextuality and its underlying elements and components can aid them to reach a more reliable and acceptable meaning of that text.

The authors take up from the ocean of other writers' work and amalgamate in their works what is relevant to create meaning, while the readers, either through their previous knowledge or by submersing in movement between the texts, attempt to understand the intended meaning. Such practice shows how a similar cultural, political, religious, or moral ideology can be manifested in many ways through different cultural practices. The modern linguists name this practice 'Intertextuality.'

Kristeva (1986) views the text as "a permutation of texts, and intertextuality in the space of a given text in which several utterances taken from other texts intersect and neutralize"(Kristeva, 1986, p. 35). For Barthes \& Duisit (1975), intertextuality is "the impossibility of living outside the infinite text" (Barthes \& Duisit, 1975). Genette's (1997) intertextuality, which he names as transsexuality, is "all that sets the text in a relationship, whether obvious or concealed with other texts". In the Oxford Concise Dictionary Of Literary Terms, Baldick (2001) defines intertextuality as "various relationships that a given text may have with other texts. These intertextual relationships include anagram, allusion, adaptation, translation, parody, pastiche, imitation, and other kinds of transformation" (Baldick, 2001).

There are multifaceted views about the term and almost everyone that comes across the term understands it differently because of its slippery nature. Given the varied views and the inclusive and comprehensive nature of the term, it defies any fixed definition. For this study, intertextuality signifies the various ways in which a literary text is built of other texts in the form of implicit or explicit allusions, adaptations, pastiche, and transformations in the form of retelling of an old story or the rewriting of popular stories in the modern context (Lundin, 1998; Reimer, 2013).

Shamsie (2017) is a modern imaginative version of Sophocles' play 'Antigone, ' transplanted out of ancient Greece into $21^{\text {st }}$ century Britain. The story unfolds amidst the growing unrest against British Muslims in the country. Kamila articulates the concerns and troubles of Muslims living in Britain who are struggling to maintain their unique religious 
and cultural identity while defending their British identity as citizens loyal to the crown. The story depicts the social and political struggle of British Muslims against the antagonizing forces that wish to isolate them.

The novel loosely follows Sophocles' Antigone, but Kamila has transformed the play in the arena of its genre, from play to novel, the names of the characters, the setting, and plot, to adequately depict the issues she wants to address, as well as to avoid anachronism. The transformation of the genre is probably because today's novel offers a more popular and effective means to propagate the intended message, compared to the tradition of drama, which was popular in ancient Greece but started to decline after the modern period (Eubanks, 2004; Keenoy \& Cliff, 2003).

Intertextuality has roots deep in antiquity. Literature everywhere is intertextual whether the writer intends or not. This paper is dedicated to exploring intertextuality weaved into the novel, which establishes its deeper meaning by building and drawing upon other texts. The investigation of intertextual underpinnings of the novel will show the significance of the concept itself, for it will show how different cultural, social, political, and moral ideologies can be manifested in various ways over different cultures and periods. Hence, it is important for the understanding of the text that the intertextual elements be traced and the contribution of these elements in the meaning-making process be explored. Hence, the main ideas being explored here are related to identifying which intertextual elements have been used and how these contribute to the production of meaning in the novel.

\section{REVIEW OF LITERATURE}

Etymologically the term "intertextuality" has been derived from the Latin word intertext which means to intermingle while weaving. The term emerged during a period of transition and has roots in linguistics. Structuralism was a hot debate in France in the middle the to late 1960s, leading to what is now known as poststructuralism. Hence, intertextuality is a poststructuralist, deconstructionist concept. Kristeva, a French linguist, coined the term in the late sixties while attempting to blend the theories of language and literature by Saussure (Theory of Sign) and Bakhtin (Dialogism). This attempt led to the emergence of the first theory of intertextuality.

In her essay, "Word, Dialogue, and Novel," Kristeva (1986) breaks away from the conventional notions about the influence of author, text, and source of text. She charges on the concept of stable signification in Saussure's semiology. Saussure, who is dubbed as the father of modern linguistics, regarded language as a closed, self-contained semiotic system. In her works, Kristeva (1986) examines that structuralist semiotics emphasize the objectivity of language, ignoring the human subject which is the performer and articulator of the utterance under consideration, positing that all signifying system constitutes in a manner that transforms earlier signifying systems, that is to say, signifiers are plural, containing historical meaning and are not directed to stable signified. She demonstrates that a text is the construction of several ideas with various meanings, challenging the structuralist notion of closure of text. It is here where Kristeva's theory of intertextuality transpires.

Allen (2006) defines intertextuality as an "attempt to understand literature and culture in general"(Allen, 2006, p. 7). He calls it "a cultural and historical term," which is "often associated with notions of pastiche, imitation and the mixing of already established styles and practices". He stresses the usefulness of the concept because "it foregrounds notions of rationality, interconnectedness, and interdependence in modern cultural life," establishing that literature comes from systems, codes, traditions, and culture which are imperative for understanding meaning. Modern theorists deny independent meaning to a work of art and hence, "the act of reading [...] plunges us into a network of textual relations. To interpret a text, to discover its meaning or meanings is to trace those relations. Reading thus becomes a process of moving between texts" (Allen, 2006, p. 1). Making it the job of the reader/interpreter to move between the texts and pursue the intertextuality, explicit or implicit, to reach the meaning of the text. Thus making the text become the intertext (Allen, 2006; Leitch, 1983; Naderi \& Motlaqh, 2017; Plett, 1991).

According to Allen (2006), "the words we select in any specific situation have an 'otherness' about them: they belong to specific speech genres, they bear the traces of previous utterances. They are also directed towards specific 'others', specific addressees". Allen (2006) cites Bakhtin (1981).

The speaker is not the biblical Adam, dealing only with virgin and still unnamed objects, giving them names for the first time In reality any utterance, in addition to its own theme, always responds (in the broad sense of the word) in one form or another to others' utterances that precede it. (Bakhtin, 1981)

Allen (2006) notes that it is this sense of otherness that explains Bakhtin's concept of dialogism and initiates to demonstrate the concept's intertextual nature (Allen, 2006, p. 21). Allen (2006) observes that Bakhtin never uses the term intertextuality himself in his study of Dostoevsky. He constructs the concept of dialogism, which is the idea that all utterances are dialogic. They occur in a social milieu and are thus in a dialogue with what has already been said, how they will be received, and what may be said in response.

Jesus and Alfaro (1996) explain dialogism as "dialogue not only with other human beings and with ourselves but also with the natural and the cultural configurations we lump together as "the world" (p. 272).

Kristeva (1986) posits, "What allows a dynamic dimension to structuralism is his [Bakhtin] conception of the 'literary word' as an intersection of textual surfaces rather than a point (a fixed meaning), as a dialogue among several writings: 
that of the. writer, the addressee (or the character) and the contemporary or earlier cultural context". For Kristeva, a literary text, then, should be considered in light of its relationship with other texts and to the structures of language, instead of sole ownership by the author. Bakhtin's key insight is that "any text is constructed of a mosaic of quotations; any text is the absorption and transformation of another" (Word, Dialogue and Novel, 36-37 by Kristeva, 1986) Her important works such as The Bounded Text and Word, Dialogue, and Novel echo these poststructuralist ideas. In these works, she sets the floor for the mode in which text is constructed out of an already existing discourse. She argues that authors do not come up with something new but develop their ideas from already existing texts. In other words, the text's meaning comes from the temporary rearrangement of elements that have socially pre-existent meaning. Theory of intertextuality posits that the meaning of a text is not fixed in itself because every text is an intertext. Hence, she defines text as 'A permutation of texts, and intertextuality in the space of a given text,' in which 'several utterances, taken from other texts, intersect and neutralize one another.'

Allen (2006), citing Barthes \& Duisit (1975); Latham (2008), says "[t]he idea of the text, and thus of intertextuality, depends on the figure of the web, the weave, the garment (text) woven from the threads of the 'already written' and the 'already read'( p. 6). Lundin (1998) further explains it this way: 'Texts draw upon texts, which themselves are based on yet different texts. The meaning is produced from text to text; new worlds are made out of old texts" (p. 210).

Elusive in nature intertextuality resists definition. Due to its comprehensive and evolving nature, 'it can be compared to a college as a work of art and in terms of literature; it is better known as a discourse of multiplicity and plurality of meaning, ideas, beliefs and realities' (Saaed and Fatima, 2018). It is a critical concept that has been taken up by many literary theorists who have given it their interpretation. Plett (1991) claims in his essay, Intertextualities, '[A]lmost everybody who uses [the term] understands it somewhat differently', cites Latham (2008). For Barthes \& Duisit (1975), it is a multidimensional space in which a variety of writings, none of them original, blend and clash. Allen (2006), accounts that the key characteristic of intertextuality to be the introduction of 'a new way of reading which destroys the linearity of the text,' and that, 'Intertextuality speaks a language whose vocabulary is the sum of all existing texts' (Allen, 2000, p. 13-113). Bazerman \& Prior (2003) are of the view that texts are created out of a sea of already existing texts that surround us, and we understand them because they are from the same sea, terming this relationship between texts as intertextuality. Bazerman \& Prior (2003) further elaborates that 'intertextuality is not just a matter of which other texts you refer to, but how you use them, what you use them for, and ultimately how you position yourself as a writer to them to make your own statement' (p. 94). Theorists such as Riffaterre and Genette while dealing with the concept of intertextuality attempt to delimit the boundaries set by Kristeva and Barthes as they appear to be difficult to apply to the practical analysis of texts. Allen (2006) states, that Genette with his structuralist approach considers that 'the ability to constitute a system is precisely the characteristic of any set of signs, and it is this constitution that marks the passage from pure symbolism to the strictly semiological state,' so the essential thrust of the structuralist project is intertextual. Denying the unitary objects and emphasizing their systematic and relational role whether they are literary texts or other works of art. Genette's views do not concern individual symbols or works but the functioning of signs and texts as the fruit of systems, codes, cultural practices, and rituals that are describable (Allen, 2006, p. 95).

In Structuralism and Literary Criticism, Genette's influential essay, he elaborates on Claude Lévi- Strauss's notion of the bricoleur which, in essence, means someone engaging in bricolage or creating a structure out of previous structures by rearranging elements but the resultant structure is not identical to the original (96). Allen (2006) notes that literary works, for theorists such as Genette, "are not original, unique, unitary wholes, but particular articulations (selections and combinations) of an enclosed system," for Genette, "literary "production" is a parole, in the Saussurean sense, a series of partially autonomous and unpredictable individual acts; but the "consumption" of this literature by society is a langue'( p. 96).

\section{METHODOLOGY}

The text of Home Fire will be qualitatively analyzed from the postmodern perspective of intertextuality in the light of Genette's (1997) proposed divisions of intertextual relationships. Genette divided transtextuality into five parts. He coined the term "transtextuality" for his version of intertextuality. Transtextuality is a generic term for all types of textual relationships. The divided parts are namely: Architextuality, Paratextuality, Metatextuality, Hypertextuality, and Intertextuality, as demonstrated in the figure below. However, due to the constraints of time and word limit, the current study will focus on only three aspects of transtextuality i.e. intertextuality in the form of references and quotations, paratextuality in the form of peritext and epitext, and hypertextuality on the levels of hypo- and hyper-text.

Architextuality entails general categories such as discourse types, the use of language, and genres etc. Genette's intertextuality refers to the mutual presence of text, that is to say when some part of a text is present in another then an intertextual relationship exists. Moreover, the limits intertextuality to quotations, allusions, and plagiarisms (Allen, 2006, p. 101). Metatextuality includes commentary of one text on another, uniting the two texts without necessarily citing or naming it (p. 102). Paratextuality or paratextual elements lie at the threshold of the text controlling the reception of the play by readers and are formed of two layers or levels. The paratext consists of a peritext, which includes book titles, chapter titles, epigraphs, prefaces, and notes, etc. The epitext, the second layer, consists of promotions, advertisements, interviews, reviews, letters, and discussions (103) the last division, hypertextuality, which in turn is formed of two layers a hypertext and a hypotext. The hypertext is the newer text that is influenced by some older text, the hypotext. The two 
unite the text in such a way that one is not the commentary on the other (108).

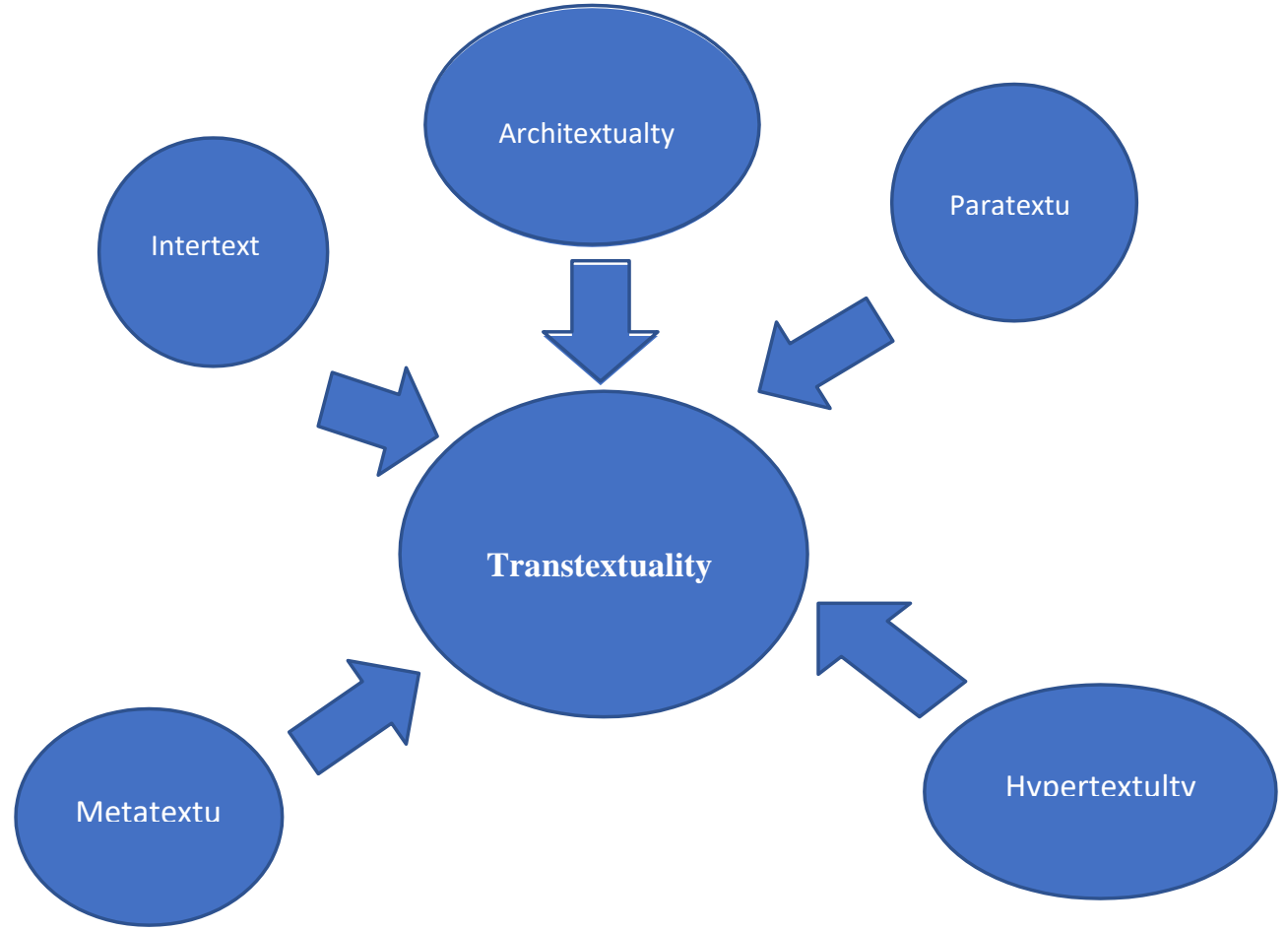

Figure 1: Transtextuality and types of textual relationships

\section{Intertextual Analysis of Home Fire}

To explore the types of intertextuality interweaved into the novel, the text of Home Fire is analyzed under parameters proposed by Genette. The fabric of the novel is interleaved with intertextuality. As the text is fragmented into respective intertextual types the meaning sustained within will be unearthed.

\section{Quotations and Allusion:}

Intertextual allusions become visible from the very first pages of the novel and are dispersed all over the length. The novel opens in an airport investigation room where Isma, the eldest of the Pasha siblings, is detained before she can board the airplane for America. The questions she is asked reference and makeup allusions to many controversial subjects of the world. For Isma to establish her identity as a British citizen she is made to answer questions on 'the Queen, democracy, The Great British Bake-off, the invasion of Iraq, Isreal, suicide bombers, dating websites" and also on the feud between Shias and Sunnis which is an allusion to the embittered civil war in Syria and the emergence of ISIS.

The integration of Quranic verses in the novel from chapter eighty-six, Al Tariq, reads: by the sky and the night visitor!/ And what is the night visitor? / A piercingly bright star (Home Fire chapter 2,43). These verses come to Aneeka's mind soon after the scuffle with Isma over their responsibilities toward the state and their estranged brother. These verses learned from her grandmother, are her solace in the face of powerlessness. The fact that they are now just words in a foreign language epitomizes Aneeka's estrangement and distance not only from her roots but also from people close to her. These verses transform into a sense of security and hope for Aneeka. The verses tell of a 'night visitor' which in the context of the Quran is Allah watching over all the souls in the universe and everything in between the earth and sky. While the western culture may interpret it as the guardian angels designated to protect every human being, the Islamic scholars agree on the stars being the angels assigned by Allah to watch over humans and record their deeds. The quick flash of the verses serves as the realization of her resignation and powerlessness.

Another verse from the second chapter of the Quran inculcated in the novel: "la yukallifullahu nafsan ilia wus-ahaa. Allah does not burden a soul with more than it can bear" (Chapter 2) affirms hope and faith in Isma, who had framed the handwritten verse after the death of her grandmother. The intertextual quotation of Quranic verses signifies their resolution in the face of hardship. Despite having to suffer on an everyday basis due to rising islamophobia the family remains together steadfast. Their grandmother had these verses tapped to her bedside table drawer as long as she was alive. Later, when Eamonn finds these verses their meaning invites Eamonn's pity for Isma, who himself is estranged from this feeling of contentment despite having Muslim roots.

Shamsie shows the contrastive nature of the use of verses from the Holy Quran by those who use and interpret it out of context. The extremist's misinterpretation and misrepresentation for personal endeavors are made evident through Farooq's quotation of a Quranic verse to brainwash Pervaiz against his family, epitomizes Shamsie's use of intertextuality 
to exfoliate the true nature of the extremists. Their interpretations of the verses and stripping off of the context in which they appear represent how the enemies of Islam are, in fact, the pro-ISIS (Islamic State of Iraq and Syria). Farooq convinces Pervaiz that he is wasting away his life by following his sister's will when he should be the one controlling them. To validate his claim he quotes from the Quran's second chapter, Al-Nisa, he says: " men are in charge of women because Allah has made one of them excel the other. And by Allah's law, you, not your women, dispose of your property". Farooq's efforts were to convince Pervaiz that he had been growing up seeing an 'emasculated' version of Islam, is Shamise's intention to let the readers contemplate how manipulative opportunists and extremists, like Farooq, can be to attain their goals. Shamsie makes another allusion to a Quranic verse to show the selective reading on part of people when it comes to Quran. Hira Shah, Isma's professor, encourages her to not muffle her feelings and desires when she suspects her to be bothered by Eamonn. She says, "you know the Quran tells us to enjoy sex as one of God's blessings?" to which Isma replies "within marriage." Shah retorts that "we all have our versions of selective reading when it comes to the holy book."(Chapter 2)

Shami Chakrabarti's words against the proposition of stripping certain British Nationals, suspected of terrorist connections, off of their nationality, are directly quoted in the novel. Shamsie uses Chakrabarti's words delivered while she was the director of Liberty, a human rights organization in Britain, to reinforce the prejudice of the imminent Immigration Bill that caused fear in many British citizens. She quotes from Shami: "Removing the right to have rights is a new low. Washing our hands of potential terrorists is dangerously short-sighted and statelessness is a tool of despots, not democrats"(Chapter 7, X)

Shamsie alludes to old Pakistani songs that depict Isma's inner complex over her looks. Having beautiful and fair skin would get her anything in the world, even the affection of Eamonn. While the song is mentioned to be Pakistani, the lyrics also match a famous song "Chaiya Chaiya" from an Indian film "Dil Se", which ends in the same way the novel ends. The main characters dying in a bomb attack in each other's embrace. Whether the similarity is purely a coincidence or intended by Shamsie is not clear.

There is also an allusion to Greek mythology figures, Icarus and Daedulus, and the incident of their unfortunate fall from the sky, mirroring the situation of her brother and father but in reverse order. Their father is the one dragging their brother down.

An example of political allusion is made evident by Shamsie, by alluding to the British Muslims who declared not to carry out Islamic obsequies for British Muslim terrorists, echoing through the Mosque imam refusing to hold a funeral for Pervaiz. The allusion to the folklore of Laila Majnu and Sassi Punnu are made paralleling Aneeka's situation after the death of her beloved brother. The well-known tale of Laila and Qais, who grew up together and fell deeply in love. Laila's father opposed their love. Qais was obsessed with her and that earned him the title 'Majnun' (Crazy) from the fellow tribesmen. Laila was married to a nobleman. When the news reached Majnu he fled the tribe and wandered in the desert, eventually dying in the desert. Sassi and Punnu share a similar fate with Laila and Majnu. Sassi and Punnu fell in love instantly after they met. Both their families opposed their union. They were cheated and separated on their wedding day. Sassi, after finding out the truth, ran bare feet to town and journeyed across the desert to find Punnu, however, both of them dyed in the desert searching for each other. These allusions foreshadow Aneeka and Eamonn's fate and the sacrifice they will have to make for the ones they love. In Karachi, Aneeka wanders through the park just as senselessly as Majnu did after losing Laila, and as Sassi roamed around the city barefooted in search of Punnu. The intertextuality here compels the reader to gauge the love Aneeka had and the grief she was going through and her mental state after losing her twin brother.

\section{Paratextuality}

Paratextuality will be discussed on two levels: the peritext and the pretext.

The Peritext: Allen (2006) quoting Genette states, "the paratext consists, as [the] ambiguous prefix suggests, of all those things which we are never certain to belong to the text of a work but which contribute to present - or "presentity" - the text by making it into a book."(104) The paratext is crucial to the reception of the book by the readers. It establishes a milieu for the reader to position the book in the plethora of other texts. The paratextual aspects of the novel inform the reader of the context and the content. The novel has been written in the wake of emerging unrest among the British citizens for Muslims, especially the 7/7 attacks. A state of situation where many terror attacks carried out in Britain identified the perpetrators as British Muslims and the state was getting ready to deal with it without considering the sensitivities of British Muslims.

The title of the book 'Home fire' a word which means fire burning in the hearth of the home. The pair of words frequently used figuratively for the crumbling condition of family life. Shamsie employs the word in both meanings. A fire burning inside the Pasha household that had engulfed everything and as a fire burning in England that had brought the individuals from the multiethnic society of Britain to stand against each other.

The epigraph for the novel is a quote from Seamus Heaney's version of Antigone titled: The Burial at Thebes: Sophocles Antigone. The epigraph quotes:

"The ones we love... are the enemies of the state" 
The epigraph aptly puts the expectations about the content of the novel and its story into context for the reader. The reader can understand what the main conflict of the novel is and what to expect from the story. The novel is divided into four parts named after each main character, which is then told from the character's point of view. Insight into the very character's mind is of crucial significance in the novel since it provides an understanding of the choices made by the characters, their actions, and reactions to everything that was happening with and around them.

The Epitext: The Guardian reviewing Shamsie's Home Fire reveals that Shamsie's prose is evocative and elegant. The novel strikes a perfect balance between the powerful exploration of contemporary society, family, and faith, while at the same time addressing the same dilemma that has been prevalent since ancient times. The review also suggests that Shamsie's adaptation of Antigone is more accredited to the version written by Jean Anouilh. Antigone is the older sister in the Sophoclean version, where she is extremist but also filled with piety, delivering the message that the older generation is not always right and the law of nature comes before man-made laws. While in Anouilh's version, written during the times of Second World War, the situation had become different so Antigone was not the older dutiful sister but made a younger rebel.

Aminatta Forna, a Scottish writer, opines that the 'simple' and 'lucid' prose by Shamsie is "in perfect harmony with the heartbeat" of the world's situation. She concludes that "no novel could be as timely"

In an interview with Foyles, Shamsie reveals her inspiration and motive behind writing a novel addressing very sensitive issues in the contemporary world. She claims in the interview that she while traveling to America she has been taken to secondary examination where the atmosphere would make her nervous and she would try to imagine the question they might ask and she would respond to them, but it did not happen to her directly, however, she has had the experience of its time and time again. She also reveals that Jatinder Varma of Tara Arts London gave him the idea to adapt Antigone into a modern context. The original suggestion was to write a play for his theater, but Shamsie chooses to transform the play into a novel compelled by her novelist's brain.

\section{Hypertextuality}

Hypertextuality is the viewing of texts from the two lenses of hypo-text and hyper-text. Hypo-text is the 'major source of signification for a text' serving as the intertext. The hypo-test for Shamsie's Home Fire is Sophocles' Antigone, the translated version of The Burial at Thebes: SophoclesAntigone by Seamus Heaney, and Anne Carson's translation Antigone, which she names as 'constant companions' while writing the hyper-text Home Fire. The fictional hypo-text of Antigone provides a basis for the construction hypo-text of Home Fire. The resemblance is made evident through the main characters and plot.

However, in Shamsie's novel the characters' names are adapted. Antigone becomes Aneeka, the 19 years old, stubborn, and headstrong law student who is caught in the dilemma of giving her brother a proper funeral in their homeland and at war against the state. Ismene is Isma, the twenty- eight years old $\mathrm{Ph}$. D aspirant, who hesitates to take her sister's side and wants to remain at peace with the state. Haemon is Eamonn, who is torn between his love for his father and Aneeka, and Creon becomes Karamat Lone, the home-secretary, who holds the power and represents the state, just as Creon was the king of Thebes.

The plot of the play does not strictly follow the incidents from Sophocles, instead, it acts as the basic frame. The novel is divided into five parts named after the main characters. Each part delving into the mind of the character and showing how they viewed everything that was happening, allowing the readers to see the story and judge it from their perspectives, after contemplating and deciding the antagonizing party and how it is harming everyone. Shamsie clarifies that Antigone was not the "structure or the skeleton of the book" it was rather 'in the marrow' of the book. Thus, based on the similarities between the characters, the tribulations they go through, their interactions, and their relationships with each other establish hypo-text as a major source for hypertext.

\section{CONCLUSION}

Shamsie juxtaposes the greater realities of the contemporary world by adapting a Greek tragedy and imposing a modern story on it. The ancient story is told in the context of terrorism and its effects on the life of common British Muslims who have no other option but to be dragged into it. Shamsie reworks Sophoclean tragedy to depict the complex realities of the contemporary world and the inextricably woven politics in the lives of ordinary people. This juxtaposition of the ancient world with the modern world not only establishes the human struggle as transcending time but also as universal. Problems that are not trapped in time but encompassing times, cultures, and people.

The novel captures the collective and conflicting self-consciousness of Muslims on foreign lands. Shamsie successfully captures the dilemmas and insecurities of Muslims, particularly of the British Muslims, who are struggling to stick to their religious identity while proving their loyalty to the crown when they are marginalized and alienated by the antagonizing forces for political gains.

Thus, the study concludes that through the use of intertextuality Shamsie makes the reader see that the conflict between stately authority and the common man has been the part of human lives as it was in ancient times, and that conflict is ongoing, it is eternal. However, judging from one side and not giving the other side its due, leads only to the escalation of 
the conflict into something that can only bring devastation. She leaves the final decision in the reader's hands and thinks of what the future will look like if the world continues to divide and the governments continue to strip people off of their rights in the name of the law.

\section{LIMITATION AND STUDY FORWARD}

It is important for the understanding of the text that the intertextual elements be traced and the contribution of these elements in the meaning-making process be explored. The investigation of intertextual underpinnings of the novel will show the significance of the concept itself, for it will show how different cultural, social, political, and moral ideologies can be manifested in various ways over different cultures and periods. This study shows that the face of human conflict might get changed but the integral emotions and conflicts remain the same. This implies that using intertextual references enhances the text with poignant meanings through ages. Home fire as a recent text talking about islamophobia in Britain being a retelling of a classical Sophocles play is something that.

\section{ACKNOWLEDGEMENT}

I am very sincerely thankful to all my co-authors, Saba Johar Khan, Imad Ullah Khan, Saira Asghar Khan, Laraib Rahat and Shahreena.

\section{AUTHORS CONTRIBUTION}

The introduction and literature review of this study was largely conceptualized by Saba Johar Khan. Imdad Ullah Khan and Saira Asghar Khan have made a major contribution towards the conceptualization of the area of study, data collection from diverse sources, targeted public, discussions, and conclusions. The research concepts of the study and research methodology development and analyzed by Laraib Rahat and Shahreena.

\section{REFERENCES}

1. Allen, G. (2006). Intertextuality. London: Routledge. Print.

2. Bakhtin, M. (1981) The dialogic imagination: Four essays. Austin: University of Texas Press.

3. Baldick, R., Kahng, A. B., Kennings, A., \& Markov, I. L. (2001). Efficient optimization by modifying the objective function: Applications to timing-driven VLSI layout. IEEE Transactions on Circuits and Systems I: Fundamental Theory and Applications, 48(8), 947-956.

4. Barthes, R., \& Duisit, L. (1975). An introduction to the structural analysis of narrative. New literary history, 6(2), 237-272.

5. Barton, Ellen. (2004). Linguistic discourse analysis: How the language in texts works. In Charles Bazerman \& Paul Prior (Eds.), What writing does and how it does it (pp. 57-82). Mahwah, NJ: Lawrence Erlbaum Associates, Inc.

6. Bazerman, C., and Prior, P, eds. (2003). What Writing Does And How It Does It: An Introduction To Analyzing Texts And Textual Practices. London: Rutledge, 84-94. https://doi.org/10.4324/9781410609526

7. Bhabha, H. K. (2004). The Location of Culture. London: Routledge.

8. Eubanks, P. (2004). Poetics and narrativity: How texts tell stories, in C. Bazerman and P. Prior (eds) What writing does and how it does it: An introduction to analyzing texts and textual practices, pp. 33-56. Mahwah, NJ: Lawrence Erlbaum Associates.

9. Gee, J. P. (1996) Social linguistics and literacies: Ideology in discourses, 2nd edition. London: Taylor \& Francis.

10. Genette, G. (1997) Paratexts: Thresholds of Interpretation, translated by Jane E. Lewin and foreword by Richard Macksey, Cambridge: Cambridge University Press.

11. Haynes, Natalie. "Home Fire by Kamila Shamsie Review - a Contemporary Reworking of Sophocles." The Guardian, Guardian News and Media, 10 Aug. 2017. https://www.theguardian.com/books/2017/aug/10/homefire-kamila-shamsie-review

12. Huckin, T. (2004). Content analysis: What texts talk about. In C. Bazerman (Ed.), What writing does and how it does it: An introduction to analyzing texts and textual practices (pp. 13-32). Mahwah, N.J.: Lawrence Erlbaum Associates.

13. Jesus, M. and Alfaro, M. (1996). Intertextuality: origins and development of the concept. Atlantis, 18(1/2), 268285.

14. Keenoy, T, \& Cliff, O,. (2003). Organizing textscapes. Organization Studies, 25, 135-142. https://doi.org/10.1 $177 / 0170840604038184$

15. Kristeva, J. (1986). Word, Dialogue and Novel. The Kristeva Reader. Ed. Toril Moi. New York: Columbia UP, 1986, 34-61.

16. Lundin, A. (1998) Intertextuality in Children's Literature. Journal of Education for Library and Information Science, 39(3), 210-21. https://doi.org/10.2307/40324158

17. Latham, D. (2008) "Empowering Adolescent Readers: Intertextuality in Three Novels by David Almond". Children's Literature in Education, 39, 213-22. https://doi.org/10.1007/s10583-007-9052-6

18. Leitch, V. B. (1983). Deconstructive Criticism: An Advanced Introduction, Hutchinson, London.

19. Lundin, Anne (1998). Intertextuality in Children's Literature. Journal of Education for Library and Information 
Science, 39, 210-213. https://doi.org/10.2307/40324158

20. Naderi, H., Motlaqh, B.N. (2017).The Transtextual study of — to have and have not\| and —Captain Khorshid\|. International Journal of Humanities and Social Development Research, 1(1), 5-18.

21. Plett, H. F. (1991). Intertextualities. Intertextuality. Ed. Heinrich F. Plett. Berlin: De Gruyter.

22. Reimer, M. (2013b). Mobile Characters, mobile texts: homelessness and intertextuality in contemporary texts for young people, in Barnboken tidskrift för barnlitteraturforskning/Journal of Children's Literature Research, 36. https://doi.org/10.14811/clr.v36i0.101

23. Saaed, A. and Fatima, Z. (2018). Texts within Text: An Intertextual Study of Elif Shafak's The Forty Rules of Love. NUML Journal of Critical Inquiry, 16.

24. Shamsie, K,. (2017) Home Fire. London, UK: Bloomsbury Publishing. 